BIP: Jurnal Bahasa Indonesia Prima

Vol. 3, No. 2, 2021, September 2021, PP.

\title{
ERRORS ANALYSIS OF THE USE OF COHESIVE DEVICE BY THE STUDENTS OF THE 6th SEMESTER OF STBA PIA MEDAN
}

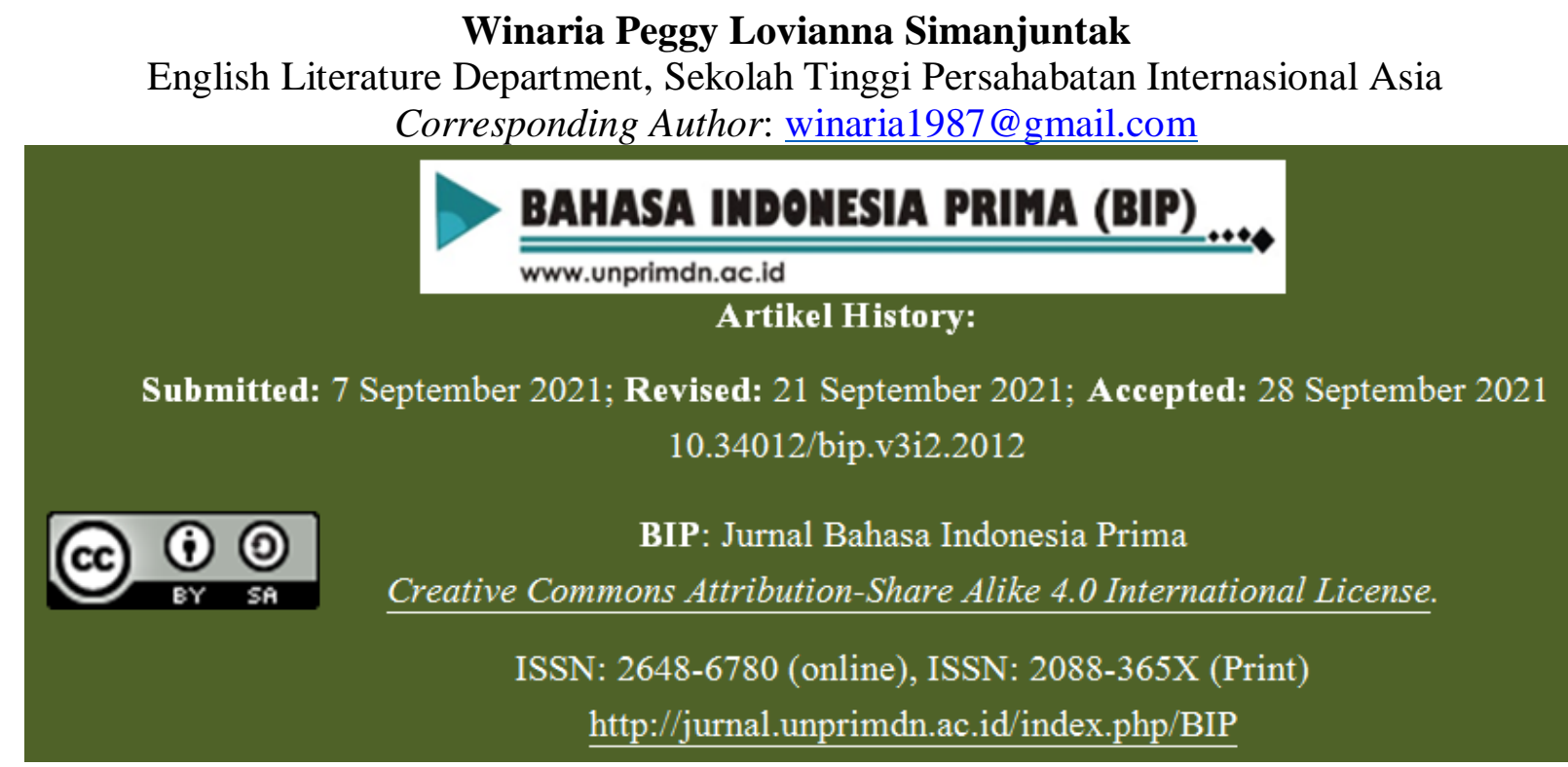

Abstract-This research aims to analyze the error of the use of cohesive device by the students of 6th semester of STBA PIA Medan in the terms of (1) the types of errors in the use of cohesive device and (2) the causes of errors in using cohesive device made by the students of 6th semester of STBA PIA MedanThis research uses Descriptive qualitative research method. The analysis of the students' errors in using cohesive device were conducted based on the category of errors, namely : addition, ommision, substitution and ordering. The data was a text of opinion ( argumentative) which were written by the students. The Results of the analysis are taken as follows : There were four types of error made by the students, namely : Errors of addition $(21,4 \%)$, errors of omission (26,8\%), errors of substitution (36,9\%) and errors of ordering 14,7 $\%)$.After the errors were viewed from the four types of the students'errors, the dominant type of errors which is made of the students is substitution (36,9\%).The causes of errors were interlingual, intralingual and disability to observe the restrictions of existing languagestructures. Keyword: error analysis, cohesive device, opinion text.

\begin{abstract}
Abstrak-Penelitian ini bertujuan untuk menganalisis kesalahan penggunaan perangkat kohesif oleh mahasiswa semester 6 STBA PIA Medan ditinjau dari (1) jenis kesalahan penggunaan perangkat kohesif dan (2) penyebab kesalahan. dalam menggunakan perangkat kohesif buatan mahasiswa semester 6 STBA PIA Medan Penelitian ini menggunakan metode penelitian deskriptif kualitatif. Analisis kesalahan siswa dalam menggunakan perangkat kohesif dilakukan berdasarkan kategori kesalahan yaitu : penambahan, penghilangan, penggantian dan pengurutan. Data berupa teks opini (argumentatif) yang ditulis oleh siswa. Hasil analisis diambil sebagai berikut : Ada empat jenis kesalahan yang dilakukan siswa, yaitu : Kesalahan penjumlahan $(21,4 \%)$, kesalahan penghilangan (26,8\%), kesalahan penggantian $(36,9 \%)$ dan kesalahan pemesanan 14,7\%). Setelah kesalahan dilihat dari keempat jenis kesalahan siswa, jenis kesalahan yang paling dominan dilakukan siswa adalah substitusi $(36,9 \%)$. Penyebab kesalahan adalah interlingual, intralingual dan ketidakmampuan untuk mengamati batasan struktur bahasa yang ada.
\end{abstract}

Kata kunci: analisis kesalahan, cohesive device, teks opini 
BIP: Jurnal Bahasa Indonesia Prima Vol. 3, No. 2, 2021, September 2021, PP.

\section{A. Introduction}

Students of English Department are expected to be able to design a text which is coherent and contextually logical. The sixth semester students of English Department have studies several types of genre of writing, as well as cohesive devices which are used to connect and to smoothen the sentences in the text. There are several factors that cause English is not successful. These factors are not only because the students learn English in a very limited time, it can also be caused by other factors such as incompetency in language, and incorrect teaching techniques.

Many Researches in the field of applied linguistics and education have distmguished between two types of errors: performance errors and competence errors. Performance errors are made by learners when they have limitation in remembering something or when are forced to speak or write fast. With a little effort of practices and approaches, these difficulties could be overcomed. However, Competence errors, relate with an adequate learning. A lack of knowledge can create greater errors.

\section{B. Review Of Literature}

Chomsky ( 1975 ) differentiates between error and mistake, error is caused by incompetence which means less understanding of the linguistics rules, however mistake is generally caused by performance. Errors happen consistently and systematically, on the other hand, mistakes happen because of the limitation of remembering or forgetting something.

Error analysis is a systematic description and explanation of error made by a learner or used in their oral or written production in target language ( Ubol : 1981 ). Moreover, Corder ( 1981 ) says that error analysis has two functions; the first was a theoritical one and the second was practical one. The theoritical aspect of error analysis is the part of the method used in investigating the language learning process. In order to find out the nature of these psychological processes, we have to have means of describing the students knowledge of the target language at a particular moments of hie or her learning in order to relate this knowledge to the teaching she or he has received.

Types of errors are based on the aspects of the grammar which are wrongly used by learners. Previously, Brown ( 1980$)$ classfied errors from the point of syntax, namely, errors of addition, errors of omission, errors of substitution, and errors of ordering.

Futhermore, Keshavarz (2012: 89), classified errors into 4 categories : orthographic errors, phonological errors, lexico-semantic errors (errors between words and meanings), and morphologicalsyntactic (errors between word forms and grammar.

According to Thambijose (2014) Orthographic errors are cognitive errors consisting of the substitution of a deviant spelling for a correct one when the writer simply doesn't know the correct spelling of a particular word or forgot it or misconceived it. One of orthographic errors example can be found in the use of identical words, such as President and presedent.

A phonological error is when a learner says one sound wrongly instead of another. When learning a new language, learners frequently make a variety of phonological errors, often because of their difficulties with the pronunciation of certain words. A common example of a Phonological Error takes form when a learner struggles to articulate words with multiple consonants grouped together; such as through, stream.

Lexico-semantic refers to how meanings are realised in texts through the lexical choices. It is stated by Eggins ( 1994) that In writing, we do not interact to exchange words or sentences, but to make 
BIP: Jurnal Bahasa Indonesia Prima Vol. 3, No. 2, 2021, September 2021, PP.

meanings, to make sense of the world to each other. This can be found on the use of improper prepositions or relative pronouns in sentences.

Previously, Brown ( 1980 ) has proposed four types of errors:

1. Addition : The phenomena when a student places a cohesive device in the place where it should not be placed.

2. Ommision : It is when a student ommits the cohesive device.

3. Substitution: This is due to a wrong word is used and it substitutes another cohesive device.

4. Ordering : When the structure of a sentence is wrong and produces confusion to the readers.

Morphology is scentific study about the structure of word and how to modify it. However, syntax concerns with the relationship between units at the level of words or morphology. According to Odlin (1989), L1 syntactic, phonetic and morphological features exert powerful influences on production of L2 structures and pronunciation. It means that the learner's ability to use and modify words into a sentence will influence the appropriate result of language production.

\section{Cohesive Device}

Cohesion is the semantic relation between one element and another in a text (Halliday \& Hasan, 1976). A text is cohesive when the elements are connected together and the text is considered meaningful to the reader. Moreover Halliday said that Cohesion occurs when the interpretation of one item depends on the other, i.e. one item presupposes the other.

For example, in the following text:

Philip bought a bag . It is black.

The interpretation of the item it depends on the lexical item a bag. Thus, the text is considered cohesive because we cannot understand the meaning of it unless the bag exists in the text.

Therefore, Halliday and Hasan classify the categories of grammatical cohesion into four types: reference, substitution, ellipsis, and conjunction.

1. Reference can be identified as the situation in which one element cannot be semantically interpreted unless it is referred to another element in the text.

2. Substitution occurs when an item is replaced by another item in the text to avoid repetition. The difference between substitution and reference is that substitution lies in the relation between words, whereas reference between meanings.

3. Ellipsis is the process of omitting an unnecessary item, which has been mentioned earlier in a text, and replacing it with nothing.

4. exical Cohesion Lexical cohesion involves the choice of vocabulary. It is concerned with the relationship that exists between lexical items in a text such as words and phrases. ( Bahaziq : 2016 )

\section{The causes of Errors}

It can be definitely stated that errors can be seen from the causes of errors which should be investigated through a research. The causes can be speculative in the sense that there may need explanations about how and why errors occur in the learning process. Touchie ( 1986 ) stated that two major sources of errors in second language learning are the interference from the native language and the intralingual and developmental factors. This means that errors can happen due to the influence of the native language. Meanwhile, intralingual problem is the difficulty to understand the second/target language.In addition to this, a research which has been conducted by Tauchid and Fatoni (2019) added a result that a negative presumption towards English 
BIP: Jurnal Bahasa Indonesia Prima Vol. 3, No. 2, 2021, September 2021, PP.

is the biggest barrier.

\section{a. Interlingual errors}

Interlingual error is caused by the interference of learner's native language. In other words, the learners tend to transfer their native language into the foreign language. The errors are caused by the interference of the learner's mother tongue, reflecting the learner's inability to seperate two languages.

\section{b. Intralingual errors}

The complicated systems of the target language can raise problems for the learner. The failure and difficulties to master complicated system of target language are the greatest reason for them in making errors.

Writing is a skill in learning English that has to be mastered by a learner. This skills relates to the ability to build a proper structure and grammatically correct sentence. Not only that, the proper use of parts of speech is required in order to create a meaningful writing. It can be assumed that writing is the most difficult skill in learning English since it is the result of acquiring the other three skills ( listening, reading and speaking).

Therefore, this research is aimed to know the types of errors in the use of cohesive device and the causes of errors made by the students of 6th semester of STBA PIA Medan

\section{Methodology}

Data play a very important role in every research because without data, the researcher will meet deadlock. This research is mainly quantitative descriptive research since the data are the errors in the use of cohesive device used by the 6th semester students of STBA PIA in their writing. The data is taken from students'writing test result in which the use of relative clauses are needed.

The population of the 6th semesterconsists of 20 students in a class.
All the samples of students'writings are used as the data. The data are in test form and is made by the researcher. The genre is opinion or persuasive paragraph.

The researcher conducted the research by assigning them to write a text from a topic of opinion/ persuasive text. The errors would be identified by underlining the errors. The first process of analyzing data is identification. The texts are examined and the errors are identified based on the types of errors. For example : With the existance of free college, people would go to college and (it would) result in more ( students) would be provided to ( go to ) college and (it will) increase taxes which will reduce the quality of education. As can be seen, the type of error made by the student is ellipsis. Student try to combine three clauses in a sentence, in which the verbs are ommited. This omission cause confusion to the readers because the sentence becomes ungrammatical.

\section{Result}

Furthermore, the table below is presented to see the total number of mistakes in using cohesive devices in students'writing :

\begin{tabular}{|l|l|l|l|l|l|l|}
\hline & $\begin{array}{l}\text { stud } \\
\text { ents }\end{array}$ & $\begin{array}{l}\text { Referen } \\
\text { ce }\end{array}$ & $\begin{array}{l}\text { Substi- } \\
\text { tution }\end{array}$ & $\begin{array}{l}\text { Conju } \\
\text { nc- } \\
\text { tion }\end{array}$ & $\begin{array}{l}\text { ellipsi } \\
\text { s }\end{array}$ & $\begin{array}{l}\text { Lexic } \\
\text { al } \\
\text { cohes } \\
\text { ion }\end{array}$ \\
\hline 1 & MA & 1 & 1 & 2 & & \\
\hline 2 & JS & 1 & & & & 1 \\
\hline 3 & VW & 4 & & 2 & & 1 \\
\hline 4 & Js & 1 & 5 & & & 2 \\
\hline 5. & CL & 1 & & & 1 & 2 \\
\hline 6. & Fan & 2 & & & 2 & 2 \\
\hline 7 & MT & 4 & & 2 & 1 & 1 \\
\hline 8 & DT & 2 & 3 & 1 & 1 & \\
\hline 9 & MB & 3 & 3 & & 2 & 2 \\
\hline 10 & JSV & 1 & 4 & & & 2 \\
\hline 11 & GM & 2 & 3 & & 1 & 1 \\
\hline 12 & IA & 3 & 5 & & 4 & 2 \\
\hline 13 & MR & 1 & 7 & & 5 & 2 \\
\hline 14 & NA & 1 & 7 & & 1 & 2 \\
\hline 15 & NS & 4 & & 2 & & \\
\hline 16 & SS & 5 & & & 3 & 1 \\
\hline 17 & OR & 6 & & & & 1 \\
\hline 18 & SH & 4 & & 1 & & 1 \\
\hline 19 & CG & 1 & & & 1 & 1 \\
\hline 20 & SL & 4 & & 2 & 1 & 1 \\
\hline TOTAL & 51 & 38 & 12 & 23 & 25 \\
in & & & & & \\
\hline
\end{tabular}


BIP: Jurnal Bahasa Indonesia Prima Vol. 3, No. 2, 2021, September 2021, PP.

types of errors identified in the students' work, namely : error of addition, error of omission, error of substitution and error of ordering. For clarifying all types of errors, the table is presented :

\begin{tabular}{|c|c|c|c|c|c|c|}
\hline \multirow[b]{2}{*}{$\begin{array}{c}\text { Erro } \\
\text { rs }\end{array}$} & \multicolumn{6}{|c|}{ Cohesive Devices } \\
\hline & $\begin{array}{c}\text { Refere } \\
\text { nce }\end{array}$ & $\begin{array}{l}\text { Substi- } \\
\text { tution }\end{array}$ & $\begin{array}{l}\text { conjun } \\
\text { ction }\end{array}$ & $\begin{array}{l}\text { ellip } \\
\text { sis }\end{array}$ & $\begin{array}{l}\text { Lexic } \\
\text { al } \\
\text { cohes } \\
\text { ion }\end{array}$ & $\begin{array}{l}\text { To } \\
\text { tal }\end{array}$ \\
\hline $\begin{array}{l}\text { Addi } \\
\text { tion }\end{array}$ & 15 & 10 & 2 & - & 5 & 32 \\
\hline $\begin{array}{l}\text { Omi } \\
\text { ssio } \\
\text { n }\end{array}$ & 10 & 15 & - & 15 & - & 40 \\
\hline $\begin{array}{l}\text { Subs } \\
\text { tituti } \\
\text { on }\end{array}$ & 21 & 7 & 3 & - & 18 & 55 \\
\hline $\begin{array}{l}\text { Orde } \\
\text { rings }\end{array}$ & 8 & - & 5 & 7 & 2 & 22 \\
\hline
\end{tabular}

The highest error made by students is error in substitution. The aim of the test is to ask students to write an opinion paragraph that contains cohesive devices which will be used as linking expressions. However, most students was mistaken the use of cohesive devices, a wrong word is used and it substitutes another cohesive device. In fact, this phenomena of substitution leads to a confusion of the sentences. The sentences with wrong cohesive devices become illogical and have no meaning.

The example of the error can be seen in this sentence :

As a result, I surely disagree if the university education should be free to everyone.

The student used the cohesive device as a result to conclude his opinion about the topic. However, this cohesive device is wrong in use. The correct cohesive device should be 'As a conclusion'or 'to conclude'. Thus the sentence will be :

"As a conclusion, I surely disagree if the university education should be free to everyone."

Another example is seen in the sentence:

"However, if you look at the last few years, the world of education can be said to be quite slumped."
The student began his opinion with a wrong conjuction. However is not used to in the beginning of a sentence, it supposed to bridge one opinion with its opposite. The best pattern for the sentence above is without a conjuction or written with another cohesive device.

It is suggested that the new sentence will be:

"To begin my point of view, if you look at the last few years, the world of education can be said to be quite slumped."

Or

"If you look at the last few years, the world of education can be said to be quite slumped."

The other error is written ungrammatically. When students try to create compound-complex sentences in order to make their writing clear and eligible, unfortunately, their new sentences become ungrammatical. When the ungrammatical sentences are appeared, the meaning is mislead. This misleading creates such confusion to the readers. Another misleading was found bcause students wrote an awkward form of sentence due to their disability in writing grammatically.

The sentence can be seen like the sample below:

Firstly because it will make it easier for everyone to get a proper education, so everyonecan get the same education at the university.

Thus, the sentence should be:

Firstly, because it will make it easier for everyone to get a proper education, so that personcan get the same education at the university.

Another example is :

It could help the students from the low class family who cannot continued their education to college just because of the college fee is too expensive and they couldn't afford it.

The sentence above is not understood because it used a wrong sentence formation 
BIP: Jurnal Bahasa Indonesia Prima Vol. 3, No. 2, 2021, September 2021, PP.

(Modal+verb base) and a wrong conjuction.

Thus, The sentence should be :

It could help the students from the low class family who cannot continue their education to college just because the college fee is too expensive and they couldn't afford it.

Furthermore, these errors were made by students because they omitted some element in the sentences. The total numebr of omission is 40 errors.

In the error of ordering, the most highlighted case is when students placed wrong conjunctions or adverbs in their sentences which lead to ungrammatical sentences. I can be seen from this sentence : Students whose grades are the highest grade in the school should receive scholarships.

The sentences above is redundant and not efficient. However, ic can be written as follows :

Students whose grades are the highest in the school should receive scholarships.

To find the percentage of errors, the formula is applied :

$\mathrm{N}=\frac{X}{Y} \mathrm{X} 100 \%$

Where :

$\mathrm{N}=$ the percentage of the errors

$X$ : Number of subcategory errors

Y : Total Number of all category errors.

The result can be seen in this table below :

\begin{tabular}{|l|c|c|}
\hline Errors & $\begin{array}{c}\text { Total } \\
\text { errors }\end{array}$ & Percentage \\
\hline Addition & 32 & $21,4 \%$ \\
\hline Omission & 40 & $26,8 \%$ \\
\hline Substituti & 55 & $36,9 \%$ \\
\hline on & & \\
\hline Orderings & 22 & $14,7 \%$ \\
\hline
\end{tabular}

After identifying the data, there were four types of errors that students have made. There were errors of addition, omission, substitution and ordering. To count the percentage of errors, the formula is used in analyzing data.
The interlingual error was happened when the student transfer their native language system into thetarget language. The students were not aware of the differences between the two languages systems. In other words, the students tend to tranfer their native language into thetarget language. The intralingual error was also encountered because the students were unable to master the target language. However, the errors were also produced because the students were unable to observe the restrictions of existing language structures. The application was often incorrect and was not contextually applied.

\section{Discussion And Conclusion}

After analyzing all the data, the conclusions can be drawn as follows :

1. There were four types of error made by the students, namely : Errors of addition $(21,4 \%)$, errors of omission $(26,8 \%)$, errors of substitution $(36,9 \%)$ and errors of ordering 14,7 $\%)$.

2. After the errors were viewed from the four types of the students'errors, the dominant type of errors which is made of the students is substitution $(36,9 \%)$.

3. The causes of errors were interlingual, intralingual and disability to observe the restrictions of existing language structures.

\section{References}

Bahaziq, Afnan. 2016. Cohesive Devices in Written Discourse: A Discourse Analysis of a Student's Essay Writing.Canadian Center of Science and Education : English Language Teaching; Vol. 9, No. 7; 2016.

Brown. H. Douglass (1980) Principles of Language Learning and Teaching. New Jersy: Practice Hall.

Chomsky, Noam ( 1975) Aspect of the 
Theory of Syntax ( London :

Longman).

Corder, S.P (1989). Error Analysys and Interlanguage (London : Oxford University Press).

Eggins, S. 1994. An Introduction to SystemicFunctional Linguistics. London: Pinter Publishers.

Keshavarz, H., Mohammad. 2012. Contrastive Analysis \& Error Analysis. Tehran: Rahnama Press.

Odlin,T., Language transfer: Crosslinguistic influence in language learning, 1989.

Tauchid, A., Fatoni, M. 2020. An Analysis of Guided Peer Review to Improve writing Skills on personal Writing Skills for High School Students in Bojonegoro. Jurnal pendidikan Edutama.

Thambijose, S. Franklin. 2014. Orthographic Errors Committed by Sophomore Students: A Linguistic Analysis. Rome : Mediterranean Journal of Social Sciences.

Touchie, Hanna. 1986. Second Language Learning Errors Their Types, Causes, and Treatment. Proceedings of the JALTJournal-Volume 8, Number 1 Ubol, C ( 1981) An Error Analysis of English Conversation. Singapore : Seameo Regional Language Center. 